\title{
FORAGE PRODUCTION ENGINEERING BY SOLAR DRYING OF VEGETABLE CROP RESIDUES
}

\author{
Said Elshahat Abdallah* Nabihah Hassan Abouelhana ** \\ Yasser Tolbah Hendawy ***Eman Ibrahim Elbadawy ****
}

\begin{abstract}
Due to animal feed shortage in Egypt, scientists are searching for an alternative feed to meet with this nutritional gap. Agricultural lands are not sufficient for human and animal needs both even in summer or winter seasons. Maximizing the utilization from agricultural by-products is the trend towards problem solving for searching an agricultural residue available in winter season besides Alfalfa to decrease the cultivated area for animal feeding purposes. Peas was at the top crops available in winter season and cultivated much in most places in Delta and besides zones and Peas residues have high content of protein. Peas residues (vine) used for animal feed and cause usually some digestion problems for animal stomach. Drying process contribution can resolve this digestion problem. A semi-cylindrical greenhouse type was used as a solar drier oriented East-West direction and located at Rice Mechanization Center, Meet Eldeebah Village, Kafr Elsheikh Governorate for drying the vegetable crop residues. A solar collector greenhouse type was utilized to provide heated air to the solar drier to enhance its thermal efficiency. The combination of solar drier and solar collector was installed at the same weather conditions during drying experiment (March 2014). The experiments of solar drying of peas residues were conducted under three different levels of drying air velocities $(0.5,1.0$ and $1.5 \mathrm{~m} / \mathrm{s})$, two chopping lengths of peas residues 3 and $6 \mathrm{~cm}$ and two drying bed depths of 1 and $5 \mathrm{~cm}$. The variation in peas residues moisture content was monitored versus drying time. The initial moisture content was of $72 \%$ wb.
\end{abstract}

KEYWORDS: Solar drying process evaluation, peas residues, exergy analysis.

\footnotetext{
* Associate Prof., Ag. Eng. Dept., Fac. of Ag., Kafrelsheikh Univ., Egypt. **Emeritus Associate Prof., Ag. Eng. Dept., Fac. of Ag., Kafrelsheikh Univ., Egypt. *** Researcher, Agricultural Engineering Research Institute, Egypt. ****M.Sc. Student, Ag. Eng. Dept., Kafrelsheikh Univ., Egypt.
} 
Drying experiments were conducted during March 2014, with an average ambient air temperature of $26.4 \pm 2{ }^{\circ} \mathrm{C}$. The ambient air relative humidity did not exceed $62 \%$ and solar radiation ranged between 597.8 and $801.2 \mathrm{~W} / \mathrm{m}^{2}$ during the experimental period. Solar radiation flux incident, air temperature and relative humidity were measured. The thermal efficiency of the solar collector and overall thermal efficiency of the solar drier were calculated. The energy and exergy analyses for peas residues during drying process via mixed-mode forced convection type solar drier were performed with the data obtained from experiments. The productivity of the solar drier was of $1.186 \mathrm{~kg}$ dried peas residues $/ \mathrm{m}^{2}$ of drier box per day. The results of the current research concluded that drying air velocity of $1.5 \mathrm{~m} / \mathrm{s}$ achieved the highest values of drying air capacity. Specific enthalpy increases by increasing drying air velocity, flow energy and internal energy. It is noticed that the drying air velocity of $1.5 \mathrm{~m} / \mathrm{s}$ also achieved the highest drying efficiency of $68.28 \%$ at (12:00PM, 3 drying hours). Peas residues chopping length of $6 \mathrm{~cm}$ and drying bed depth of $5 \mathrm{~cm}$ were the most suitable residues distribution on the drying trays.

\section{NOMENCLATURE}

$\begin{array}{ll}\mathrm{A} & \text { surface area, } \mathrm{m}^{2} \\ \text { se } & \text { specific enthalpy, } \mathrm{kJ} / \mathrm{kg} \\ \mathrm{C}_{\text {pda }} & \text { specific thermal capacity, } \mathrm{kJ} / \mathrm{kg} . \mathrm{K} \\ E & \text { exergy, } \mathrm{kJ} / \mathrm{kg} \\ \mathrm{M} & \text { mass of product to be dried, } \mathrm{kg} \\ m_{d a}^{*} & \text { maria airflow rate, } \mathrm{kg} / \mathrm{s} \\ \mathrm{M}_{\mathrm{o}} & \text { initial moisture content, } \% \mathrm{db} \\ \mathrm{M}_{\mathrm{t}} & \text { moisture content at time } \mathrm{t}, \% \mathrm{db} \\ \mathrm{W} & \text { mass of evaporated water from the product, } \mathrm{kg} \text { at time t } \\ M_{d s} & \text { mass of dry solids, } \mathrm{kg} \\ M_{W} & \text { mass of evaporated water from the product during drying day, } \mathrm{kg} \\ s h & \text { specific humidity, } \% \\ \mathrm{~W}_{\mathrm{o}} & \text { initial mass of the dried product, } \mathrm{kg} \\ \mathrm{W}_{\mathrm{t}} & \text { mass of product to be dried at any time, } \mathrm{kg} \\ t & \text { drying time, } \mathrm{s}\end{array}$




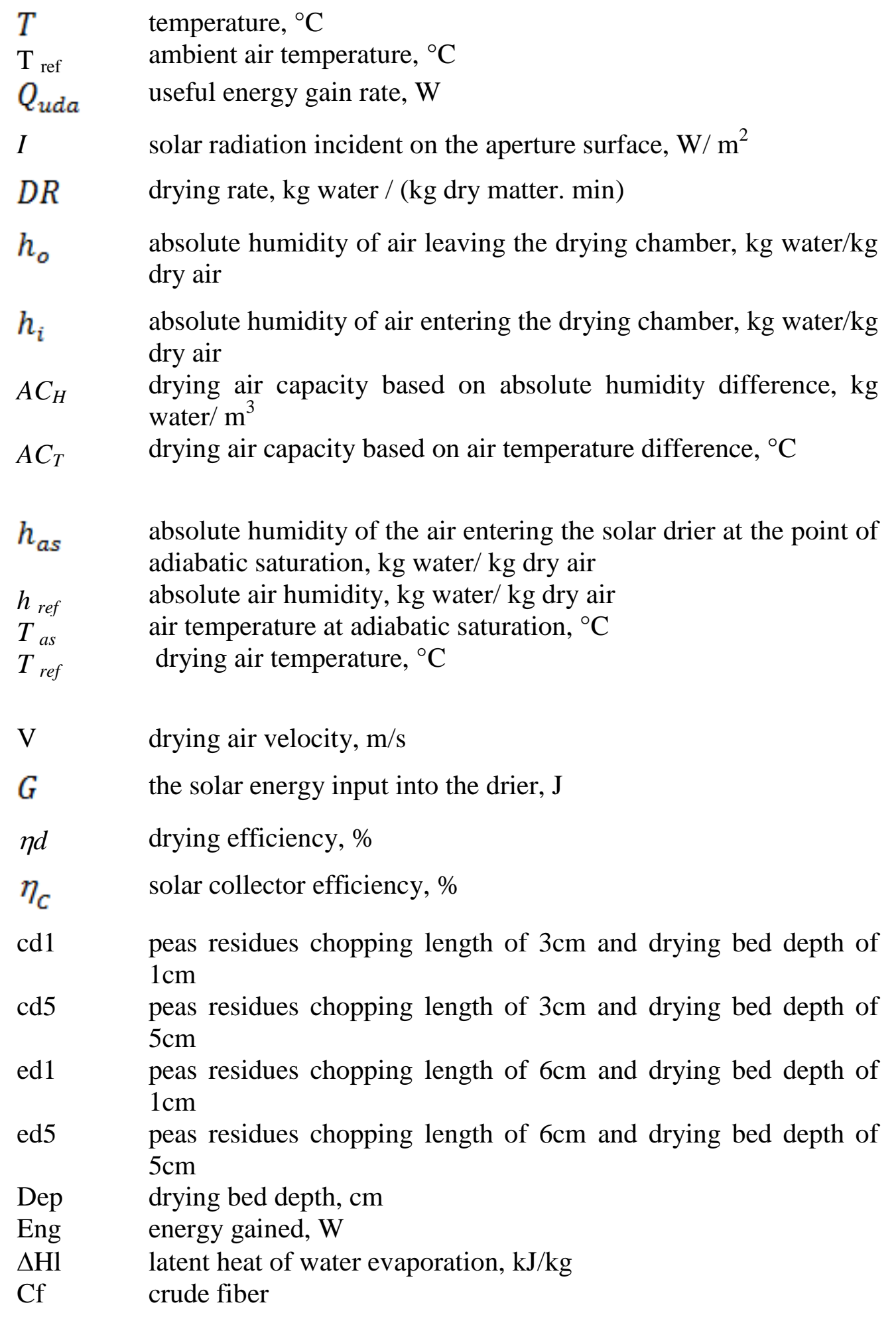




$\begin{array}{ll}\text { Cp } & \text { crude protein } \\ \text { NFE } & \text { nitrogen free extract } \\ \text { EE } & \text { ether extract } \\ \text { DM } & \text { dry matter } \\ \text { dh } & \text { drying hours } \\ \text { ci } & \text { collector inlet } \\ \text { amb } & \text { ambient } \\ \text { co } & \text { collector outlet } \\ \text { dci } & \text { drying chamber inlet } \\ \text { dco } & \text { drying chamber outlet } \\ \text { ho } & \text { heater outlet }\end{array}$

\section{INTRODUCTION}

nimal feed sources in Egypt reduce and affect the human
consumption. Nowadays problem increases to be worse as a
result of the government direction to increase the productivity of major grain crops such as wheat in winter, rice and corn in summer. This cause a competition for the cultivated area .Therefore, this investigation aims to study the possibility of providing an alternative and nonconventional forage in winter beside summer by solar drying of peas residues. Abdallah (2010) stated that there is a gap between the available quantity of green forage and the required amount of animal feed. The gap between the availability and requirement of feed is wide and the estimated shortage is 3.1 million tons of total digestible nutrients per year. The forage gap or the feed shortage has been partially narrowed to become 2.42 million tons because of using new forage resources. He also added that the drying rate which is another important factor in describing the characteristics of the drying process. He concluded that double layer covered plastic greenhouse of $4 \mathrm{~cm}$ dead air space was the best to be used because of increasing temperature and humidity reduction inside the solar greenhouse drier. [MOA (2013), in Arabic] reported that the overall production of peas green in Egypt is 169122 tons for the year 2013; peas contains $5.42 \mathrm{~g}$ of protein and $5.1 \mathrm{~g}$ fiber. Green peas contains $14.45 \mathrm{~g}$ carbohydrates and $5.67 \mathrm{~g}$ sugars. It also contains $0.4 \mathrm{~g}$ fats. Abdallah (1999) utilized the span form solar greenhouse oriented East-West to serve as a solar collector. Its longitudinal axis is facing to south to capture 
the possible maximum solar radiation. The plastic cover was of $0.1 \mathrm{~mm}$ thickness. The outside dimensions of the greenhouse were $4 \mathrm{~m}$ width and $8 \mathrm{~m}$ length. The total volumetric capacity was of $82.4 \mathrm{~m}^{3}$ of air. ElMashad (2003) revealed that agricultural wastes represent an important source of bio-energy and valuable products. In Egypt, $18 \%$ of the agricultural wastes are used directly as a fertilizer. Another $30 \%$ was used as an animal feed. The remainder is burnt directly on the fields or is used for heating in the small villages, using low efficiency burners. These wastes can be used more efficiently as a source of energy and as an organic fertilizer. The anaerobic bioconversion of these materials will result in a net energy production. The utilization of agricultural wastes for the production of energy and compost, combined with using solar energy will save fossil fuel, improve health conditions and the general life quality in the villages. Ali (1996) stated that he problem of the shortage of animal feed in Egypt is well recognized. Several efforts had been done to improve the nutritive value of agricultural byproducts. Rice straw, wheat straw, corn stalk, sugarcane, basse vine of broad bean, squash vine and other vegetable wastes were used for increasing the available feed. Abdelatif (1989) reported that Egypt is one of the countries, which has solar energy in abundance. It lies within the tropical and sub-tropical regions. It has a value of about 2.2 to $9.4 \mathrm{~kW}$ of solar energy per square meter per day, and sunshine duration per year extended to about 3000 to 4000 hours. El-Sebaii et al. (2002) revealed that all drying systems can be classified primarily according to their operating temperature ranges into two main groups of high and low temperature driers. Solar drying systems are classified primarily according to their heating modes and the manner in which the solar heat is utilized. Usage of renewable energy technologies has received a considerable attention within the past five years for their potential to help and meet with the basic needs in many countries. Solar energy is used as either the sole source of the required heat or as a supplemental source. Ekechukwu and Norton (1998) and Banerjee (2005) conducted that although, for commercial production of dried agricultural products, forced convection solar drier might provide a better control of drying air; natural convection solar drier does not require any other energy during drying process. Hence, natural convection solar 
drier is highly preferred for drying food products especially when in thin layers of drying. E1-Sahrigi et al. (1993); Pangavhane et al. ( 2002) and El-Kewey (2003) carried out a study to investigate the utilization of greenhouse for drying grain. They studied the effect of thickness of grain layers, quantity of drying air passing through the grain and agitating operation on the drying process of paddy rice. It was found that the solar drying was more efficient than natural drying in reducing the harvesting initial moisture content of paddy rice. This drying system has the effective characteristics such as simple structure, easy construction and maintenance and low cost compared with conventional driers. The outlet air temperature from the solar heater (greenhouse) was found to be affected by many parameters such as area of solar greenhouse collector, ambient air temperature outside and solar radiation available inside the solar greenhouse. They also found that, the drying air temperature was found to be directly proportional to drier area and solar radiation available inside the solar drier, but it was inversely proportional to ambient air temperature outside the solar drier. Eldreeny (2015) exploited the solar energy collected by the plastic greenhouses for drying the agricultural and industrial wastes of banana and showed that the best solar collector is the cylindrical one, based on the thermal collection efficiency. The solar drier in combination with the cylindrical solar collector achieved the highest energy utilization ratio. Akpinar et al. (2005); Akpinar et al. (2006); Celma and Cuadros (2009); Akbulut and Durmus (2010); Prommas et al. (2010) and Boulemtafes-Boukadoum and Benzaoui (2011) revealed that the air conditioning processes can be modeled as steady-flow processes that are analyzed by employing the steady-flow conservation of mass (for both dry air and moisture) and conservation of energy principles. For the energy and exergy analyses of single layer drying process, empirical equations are generally employed to compute the mass conservation of drying air and moisture, the energy conservation of the process, the relative humidity and enthalpy of drying air. Exergy is defined as the maximum amount of work which can be produced by a stream of matter, heat or work as it comes to equilibrium with a reference environment. In the drying industry, the goal is to use a minimum amount of energy for maximum moisture removal for the desired final conditions 
of the product. Several studies have been conducted on exergy analysis of food drying. The main objective of the current research is to produce non- conventional forages from vegetable crop residues via solar drying. The specific objectives are to study the effect of chopping lengths and drying bed depths on the drying rate and drying efficiency of peas residues (vine); to investigate the influence of drying air velocities $(0.5$, 1.0 and $1.5 \mathrm{~m} / \mathrm{s}$ ) on the evolution of drying rate; to enhance the efficiency of postharvest processes of agricultural production; to determine the moisture content and drying rate of peas residues and to develop an empirical equation for the drying rate which represents the solar drying process.

\section{MATERIALS AND METHODS}

The present research work was carried out at Rice Mechanization Center (RMC) in Meet Eldeebah village, Kafr Elsheikh Governorate located at $31^{\circ} 07^{\prime} \mathrm{N}$ Latitude, 30 ${ }^{\circ}$ 57'E Longitude and 20m Altitude (Abou- Zaher, 1998), Egypt during March 2014. Drying experiments were conducted with an average ambient air temperature of $26.4 \pm 2{ }^{\circ} \mathrm{C}$ measured by air temperature meter, (Model Chino HNK). Peas residues used in the current investigation were picked up and conveyed to the experimental station of RMC at an initial moisture content of $72 \% \mathrm{wb}$. The oven-drying method was used for determining peas residues moisture content at $103^{\circ} \mathrm{C}$ for $24 \mathrm{~h}$ (ASAE, 1996). Air relative humidity did not exceed $62 \%$ measured by relative humidity meter, (Model Chino HNK) and the averaged of solar radiation incident ranged between 597.74 and $801.87 \mathrm{~W} / \mathrm{m}^{2}$.

\section{Investigated variables}

Peas residues were chopped mechanically with definite lengths of 3 and $6 \mathrm{~cm}$. Samples were spread on the drying tray with drying bed depths of 1 and $5 \mathrm{~cm}$. Drying experiments were performed with four trays inside greenhouse solar drier. In all experiments, there is an additional thermal energy was supplied to the samples apart from direct solar radiation. A centrifugal suction fan was adjusted to give three levels of drying air velocity of $0.5,1.0$ and $1.5 \mathrm{~m} / \mathrm{s}$. The effect of these investigated variables on moisture content loss, ambient air temperature, air relative humidity, inlet and outlet temperatures of drying air in the greenhouse solar collector and drying chamber was studied. 


\section{Experimental setup}

A pictorial view and schematic drawing of the experimental setup, shown in Figures 1 and 2, illustrate the semi-cylindrical solar drier double covered greenhouse in combination with semi-cylindrical greenhouse type as a solar collector. A centrifugal suction fan was mounted on the tray beneath to circulate the drying air inside the drying chamber and force it to penetrate the crop residues. The solar radiation flux was measured and recorded during the drying period started from (10:00AM, $1 \mathrm{dh})$ to $(6: 00 \mathrm{PM}, 9 \mathrm{dh})$. The available solar radiation was determined every hour using the equation: $\mathrm{Q}=\mathrm{R} \times \mathrm{Ad}$ where $\mathrm{Q}$ is the available solar energy, $\mathrm{W} ; \mathrm{R}$ is the solar radiation incident on the greenhouse surface, $\mathrm{W} / \mathrm{m}^{2}$ and $\mathrm{Ad}$ is the net surface area of the drier box, $\mathrm{m}^{2}$. It was measured with a solar radiation sensor (Model H-201). Figure 3 represents the perspective drawing of the semi-cylindrical solar drier double covered greenhouse type. The semi-cylindrical solar drier double covered greenhouse type was manufactured, constructed and installed at the workshop of Rice Mechanization Center, Meet Eldeebah village, Kafr Elsheikh Governorate, Egypt. The dimensions of the greenhouse, which was used as a solar drier, are $100 \mathrm{~cm}$ width $\times 200 \mathrm{~cm}$ length $\times 80 \mathrm{~cm}$ height. The dimensions of the drying chamber are $100 \mathrm{~cm}$ wide $\times 200 \mathrm{~cm}$ long and $10 \mathrm{~cm}$ high.

\section{Drying Kinetics}

\section{Drying air capacity}

The capacity of drying air for moisture removal depends on its humidity and temperature. Drying air capacity is an important indicator determining the drying air power. Two terms are used to declare the amount of drying force or moisture tension based on absolute humidity difference and on air temperature difference. The drying air capacity based on absolute humidity is defined as the difference between absolute air humidity and the absolute humidity at adiabatic saturation or the difference between drying air temperature and air temperature at adiabatic saturation (thermodynamic wet-bulb temperature). Drying air capacity can be estimated through the following equations ( Doymaz, 2005):

$$
\begin{gathered}
A C_{H}=h_{\text {ref }}-h_{\text {as }} \\
\mathrm{AC}_{\mathrm{T}}=\mathrm{T}_{\mathrm{as}}-\mathrm{T}_{\text {ref }}
\end{gathered}
$$




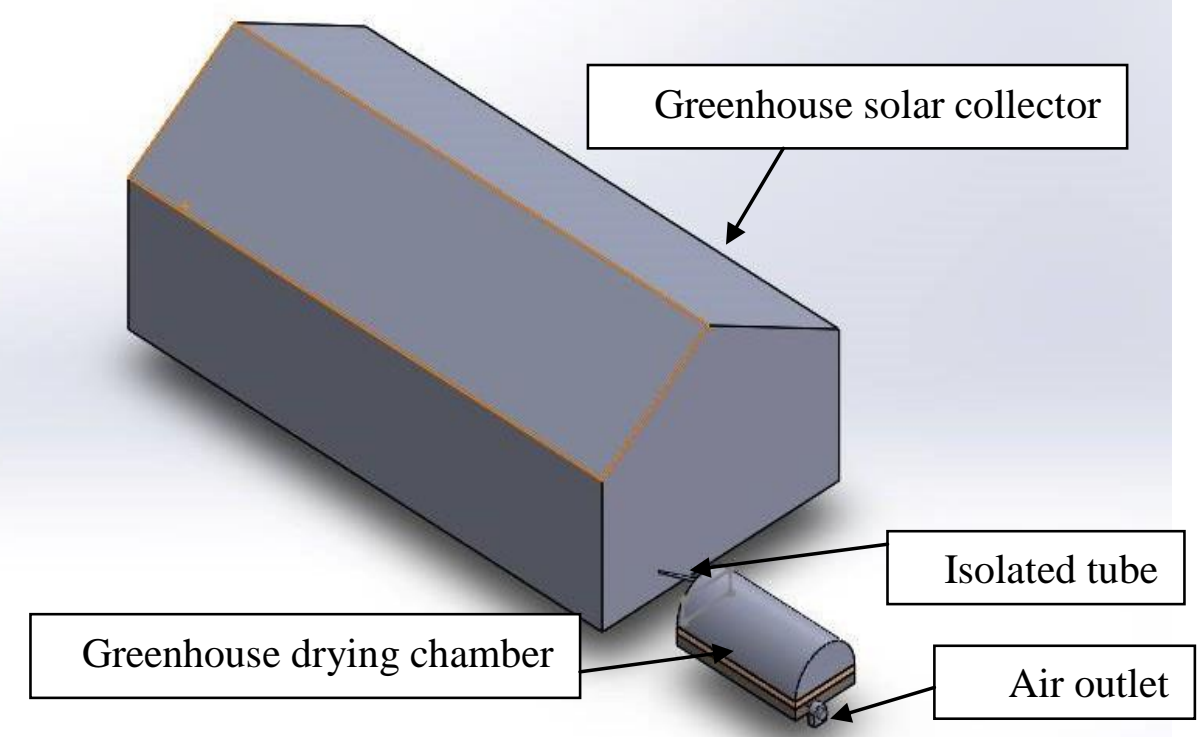

Figure 1. Pictorial view of the experimental setup

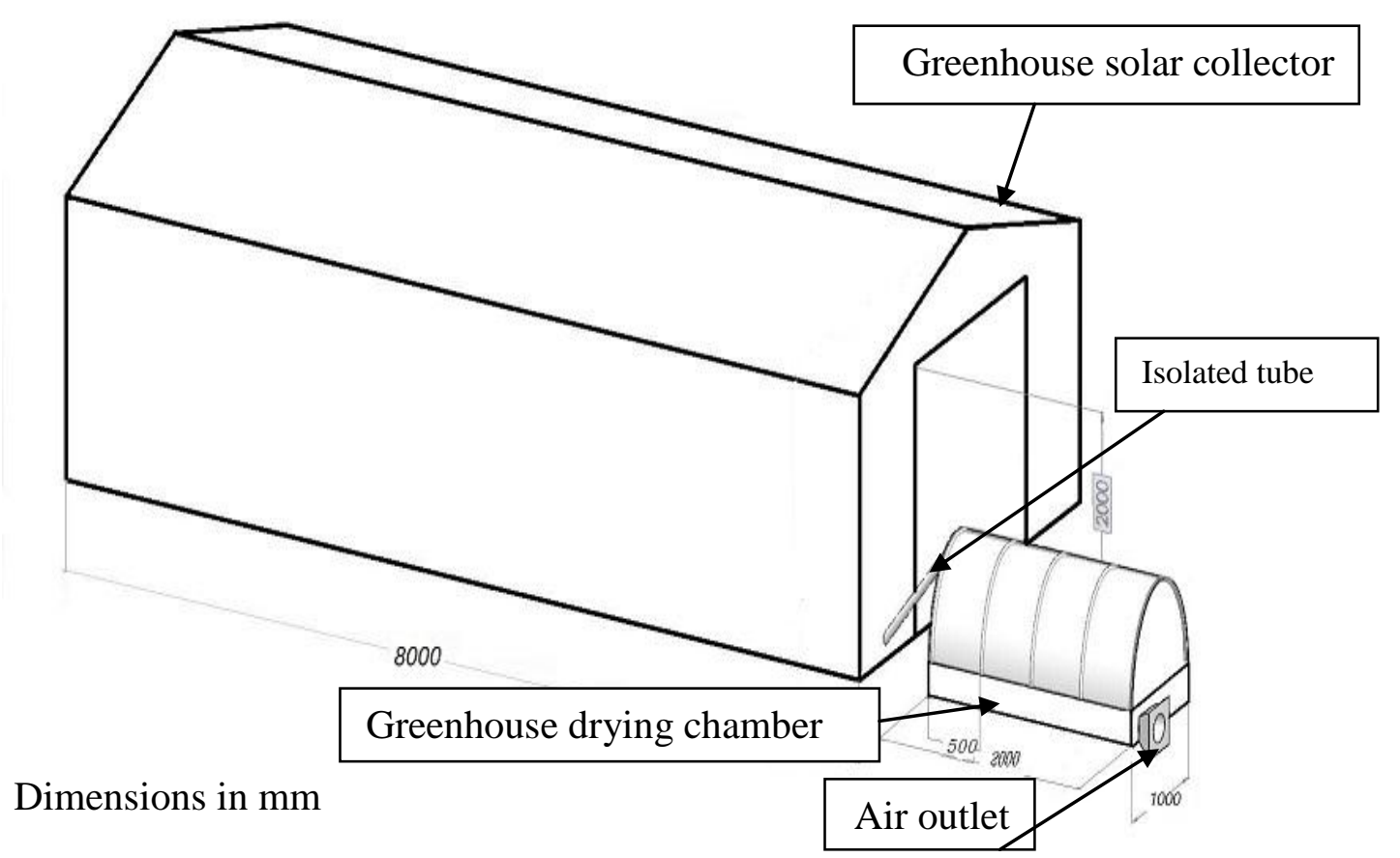

Figure 2. Schematic drawing of the semi-cylindrical solar drier double covered greenhouse type in combination with semi-cylindrical greenhouse type as a solar collector 


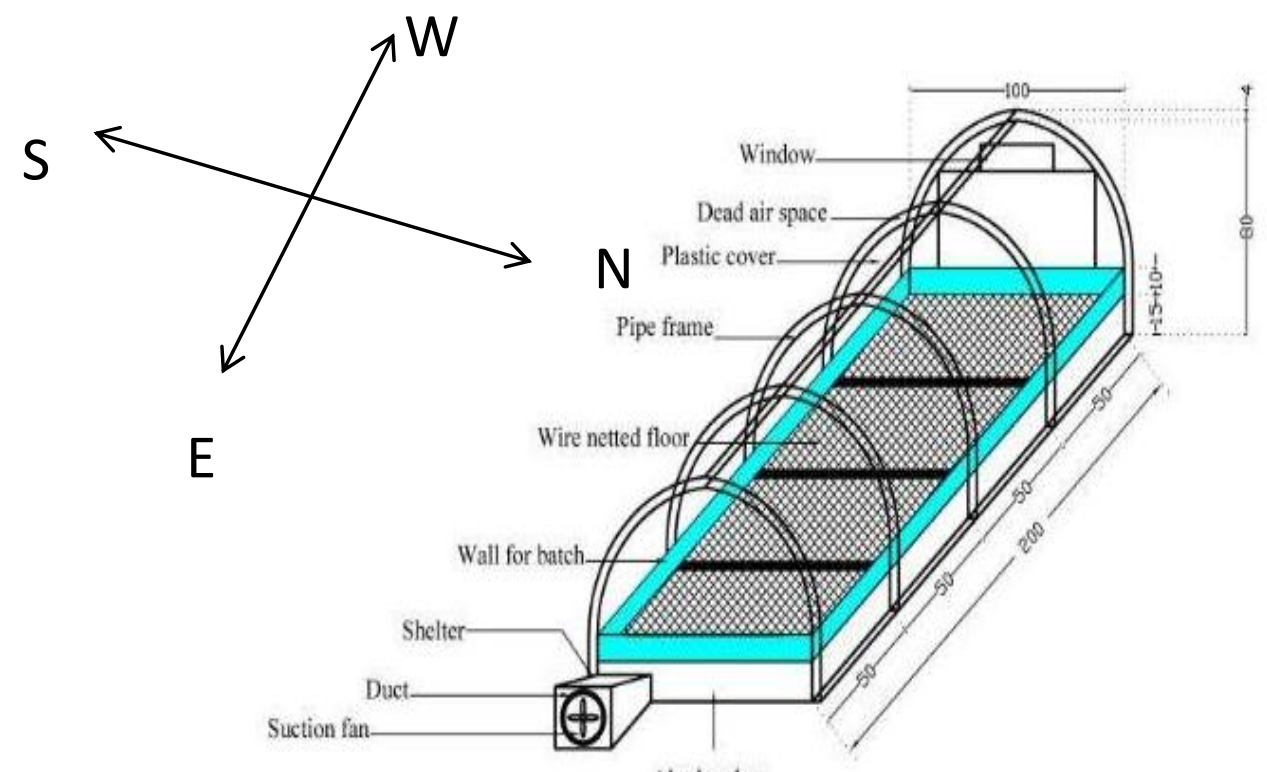

Air chamber

Dimensions in $\mathrm{cm}$

Figure 3. A perspective drawing of the semi-cylindrical solar drier double covered greenhouse type

\section{Determination of the inlet conditions of greenhouse solar collector}

The inlet conditions of the solar collector were assumed as being equal to the ambient conditions as:

$$
s h_{c i}=s h_{a m b} ; T_{c i}=T_{a m b} ; r h_{c i}=r h_{a m b} ; s e_{c i}=s e_{a m b}
$$

Where subscripts ci defines the collector inlet and amb is the ambient. Using the values of the outlet and inlet temperatures of the solar collector, the useful energy gain by the drying air, $\dot{Q}_{u d a}$, was determined by Leon et al. (2002) from equation 3 as:

$$
\dot{Q}_{u d a}=\dot{m}_{d a} C_{p d a}\left(T_{c o}-T_{c i}\right)
$$

Where $T_{c i \text { and }} T_{c o}$ refer to the drying air temperatures at the inlet and outlet of the solar collector, respectively. Provided that the psychometric transformation of wet air inside the collector is exclusively a sensible heating, resulting $s h_{c o}=s h_{c i}$, and therefore the values of relative 
humidity $\left(r h_{c o}\right)$ and specific enthalpy $\left(s e_{c o}\right)$ at the outlet of the air solar collector can be fitted using the psychometric chart.

\section{Determination of the inlet and outlet conditions of greenhouse drying chamber}

The setup of the solar drier was assumed to be such that the conditions of drying air at the inlet of the drying chamber were the same as those at the outlet of the solar air heater. This way, the small heat losses that might be developed between the heater outlet and the drying chamber inlet are neglected and subscripts dci defines the drying chamber inlet and ho the heater outlet.

$s h_{d c i}=s h_{c o} ; T_{d c i}=T_{h o} ; r h_{d c i}=r h_{h o} ; s e_{d c i}=s e_{h o}$

The values of the specific humidity of the drying air at the outlet of the drying chamber can be calculated as follows (Midilli and Kucuk, 2003):

$$
s h_{d c o}=s h_{d c i}+\frac{\dot{m}_{w p}}{\dot{m}_{d a}}
$$

Where $s h_{d c i}$ denotes the specific humidity of the drying air at the inlet of the drying chamber and $\dot{\boldsymbol{m}}_{\boldsymbol{w} \boldsymbol{p}}$ is the mass flow rate of the moisture removed from the residues on the tray. The relative humidity and the enthalpy of the drying air at the outlet of the drying chamber were estimated using the psychometric chart program. During the drying process at the tray inside the drying chamber, the heat used can be calculated by using the psychometric chart together with the following equation (Nikbakht et al., 2013; Prommas et al., 2010 and Lamnatou et al., 2012):

$$
\dot{Q}_{d c}=\dot{m}_{d a}\left(s e_{d c i}-s e_{d c o}\right)
$$

Eqn 5

\section{Exergy analysis}

Thermodynamic analysis, particularly exergy analysis, has appeared to be an essential tool for system design, analysis and optimization of thermal systems, including drying systems. Exergy is defined as the maximum amount of work which can be produced by a stream of matter, heat or work as it comes to equilibrium with a reference environment. In the drying industry, the goal is to use a minimum amount of energy for maximum moisture removal for the desired final conditions of the 
product. Several studies have been conducted on exergy analysis of food drying Dincer (2002). Exergy is a measurement of the maximum useful work that can be done by a system interacting with an environment at a constant pressure and temperature. The exergy was determined based on the following equation (Celma and Cuadros, 2009 and Fudholi et al., 2014):

$$
\text { Exergy }=\dot{m} C_{P}\left[\left(T-T_{\text {ref }}\right)-T_{\text {ref }} \ln \frac{T}{T_{\text {ref }}}\right] \quad \text { Eqn } 6
$$

\section{DRYING PROCESS PERFORMANCE ANALYSIS}

\section{Instantaneous moisture content (Mt)}

To evaluate the performance of each drying unit, a methodology proposed by Leon et al. (2002) was used in this study. The instantaneous moisture content $\left(M_{t}\right)$ on dry basis at any time can be calculated from the following equation:

$$
M_{t}=\left[\left(M_{o}+1\right)^{W_{t}} / W_{o}\right]-1
$$

\section{Drying rate}

The drying rate was found by the decrease of the water concentration during the time interval between two subsequent measurements divided by this time interval. The drying rate (DR) was therefore expressed by the following equation by (Banout et al., 2011):

\section{Drying efficiency}

$$
\boldsymbol{D R}=\frac{M w}{M d s . t} \quad \text { Eqn } 8
$$

To evaluate the drying process evolution of each solar drier overall system, the drying efficiency ( $\eta d$ ) is used. The efficiency of a solar drying system is a measure of how effectively the input energy to the drying system is used in drying product. System efficiency for the forced convection solar driers needs to take into account the energy consumed by the fan. The following equation is then used by (Banout et al., 2011):

$$
\eta_{\mathrm{d}}=\frac{\mathrm{M}_{\mathrm{W} \Delta \mathrm{Hl}}}{\mathrm{IAT}+\mathrm{PF}}
$$




\section{RESULTS AND DISCUSSION}

Figure 4 shows the daily average available solar radiations flux. Solar radiation started from $762.1 \mathrm{~W} / \mathrm{m}^{2}$ at $(10: 00 \mathrm{AM}$, 1drying hour) expressed as (daytime, drying hour) and has its maximum value of $858.76 \mathrm{~W} / \mathrm{m}^{2}$ at (12:00PM, 3 drying hour) after that it decreased until reached to $407.85 \mathrm{~W} / \mathrm{m}^{2}$ at (3:00PM, 6 drying hour) during drying experiment. Figure 5 shows the measured drying air temperature during the drying experiment at three different drying air velocities of $0.5,1.0$ and $1.5 \mathrm{~m} / \mathrm{s}$. The gradually increasing in the temperature of the drying chamber was affected by the increasing of ambient air temperature and solar collector air temperature because of increasing solar radiation until it reached its peak and then begin to decrease, at drying air velocities of $0.5,1.0$ and $1.5 \mathrm{~m} / \mathrm{s}$. The drying air temperatures of the drying chamber were of 60.8 , 57.2 and $47.5^{\circ} \mathrm{C}$ at (12.00PM, 3dh) for drying air velocity of $1.5,1.0$ and $0.5 \mathrm{~m} / \mathrm{s}$, respectively. It can be noticed that the highest drying air temperature inside the drying chamber was achieved at drying air velocity of $1.5 \mathrm{~m} / \mathrm{s}$ due to the distribution method of hot and cold air inside air column of the solar collector was as layers (thermo stratification). The highest air temperatures were concentrated at top layers and boundary layers of collector walls. On the other side, the bottom layers have the lowest air temperature. Air duct located at solar collector bottom for drying air transferring to drying chamber. The initial suction of drying air was from the bottom layers, the lowest air temperatures. With the increasing of drying air velocity, the suction rate from the collector increased as follows, which causes a mixture among air layers generates a circulation inside the collector, more circulation gives higher air temperature. Drying air temperature started from $45,46.9$ and $55^{\circ} \mathrm{C}$ and ended at $29.5,28.1$ and $39.4^{\circ} \mathrm{C}$ at drying air velocities of $0.5,1.0$ and $1.5 \mathrm{~m} / \mathrm{s}$, respectively. Figure 6 illustrates the air relative humidity has its maximum value of $65.7 \%$ at $(4: 00 \mathrm{PM}, 7 \mathrm{dh})$ and drying air temperature of $20.7^{\circ} \mathrm{C}$ and its minimum value of $43.1 \%$ at $(2: 00 \mathrm{PM}, 5 \mathrm{dh})$ and drying air temperature of $23.9^{\circ} \mathrm{C}$ at drying air velocity of $0.5 \mathrm{~m} / \mathrm{s}$. The same behavior was obtained at drying air velocity of $1.0 \mathrm{~m} / \mathrm{s}$ as ambient air temperature increases to $29.8^{\circ} \mathrm{C}$ at (12:00PM, 3dh) its air relative humidity decreases to $44.1 \%$ and as ambient air temperature decreases to $22.7^{\circ} \mathrm{C}$ at $(5.00 \mathrm{PM}$, 
$8 \mathrm{dh}$ ) its relative humidity increases to $61.5 \%$. Similarly at drying air velocity of $1.5 \mathrm{~m} / \mathrm{s}$, as ambient air temperature increases to $32.2^{\circ} \mathrm{C}$ at (12:00PM, 3dh) its relative humidity decreases to $37.2 \%$ and as ambient air temperature decreases to $23.4^{\circ} \mathrm{C}$ at $(5.00 \mathrm{PM}, 8 \mathrm{~h})$ its relative humidity increases to $50.6 \%$.

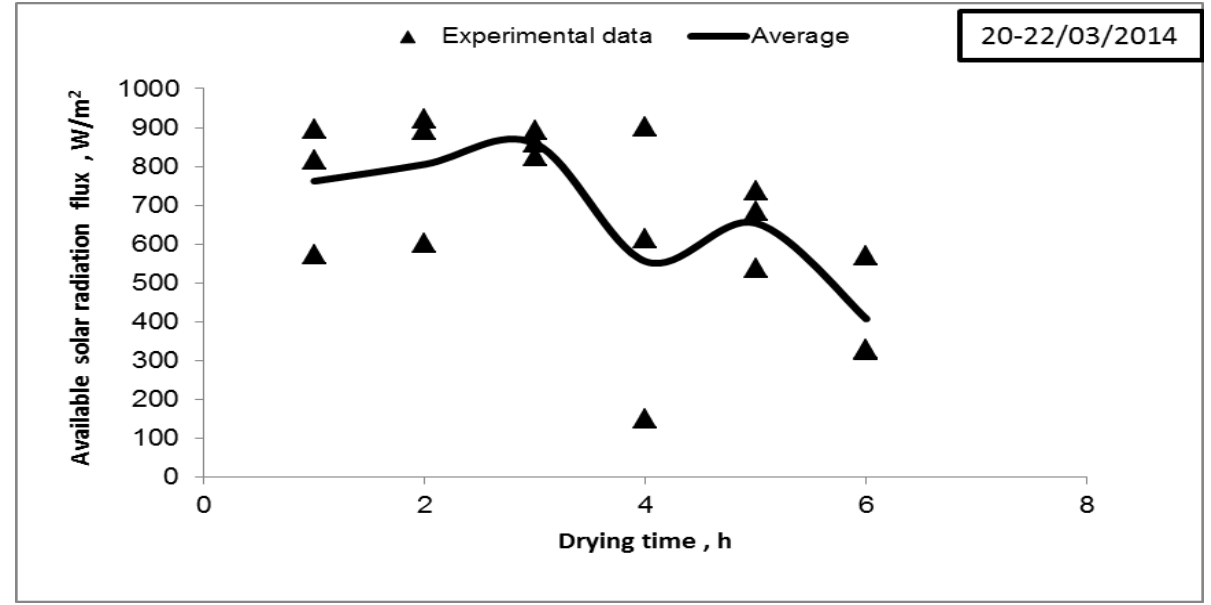

Figure 4. Available solar radiation flux as a function of drying time during the drying experiment

Figure 7 shows drying air capacity based on absolute humidity difference and based on temperature difference variations of the solar collector and drying chamber as a function of drying time. The highest values of drying air capacity were achieved at daytime period from (12.00PM, 3dh) to (2.00PM, 5dh) for all the experimented drying air velocities. The drying air capacity based on absolute humidity and temperature difference are raised from $0.000219 \mathrm{~kg}$ water $/ \mathrm{m}^{3}$ dry air and $4.92^{\circ} \mathrm{C}$ of the ambient air temperature to $0.00093 \mathrm{~kg}$ water $/ \mathrm{m}^{3}$ drying air and $6.53^{\circ} \mathrm{C}, 0.0058 \mathrm{~kg}$ water $/ \mathrm{m}^{3}$ dry air and $5.93^{\circ} \mathrm{C}$ to $0.00072 \mathrm{~kg}$ water $/ \mathrm{m}^{3}$ dry air and $6.62^{\circ} \mathrm{C}$ and $0.00128 \mathrm{~kg}$ water $/ \mathrm{m}^{3}$ dry air and $8.93^{\circ} \mathrm{C}$ to $0.00310 \mathrm{~kg}$ water $/ \mathrm{m}^{3}$ dry air and $11.22^{\circ} \mathrm{C}$, respectively at drying air velocities of $0.5,1.0$ and $1.5 \mathrm{~m} / \mathrm{s}$, respectively. The drying air velocity of $1.5 \mathrm{~m} / \mathrm{s}$ achieved the highest values of drying air capacity due to thermo stratification phenomena. Once the drying air enters the drying chamber, the drying air capacity decreases from 0.00534 to $0.00455 \mathrm{~kg}$ water $/ \mathrm{m}^{3}$ dry air and from 0.00324 to $0.00283 \mathrm{~kg}$ water $/ \mathrm{m}^{3}$ dry air for drying air velocities of 0.5 and $1.0 \mathrm{~m} / \mathrm{s}$, respectively. These losses are due to moisture migration from the dried 
product. But at drying air velocity of $1.5 \mathrm{~m} / \mathrm{s}$, the drying air capacity of $0.00751 \mathrm{~kg}$ water $/ \mathrm{m}^{3}$ dry air is still raising inside drying chamber because

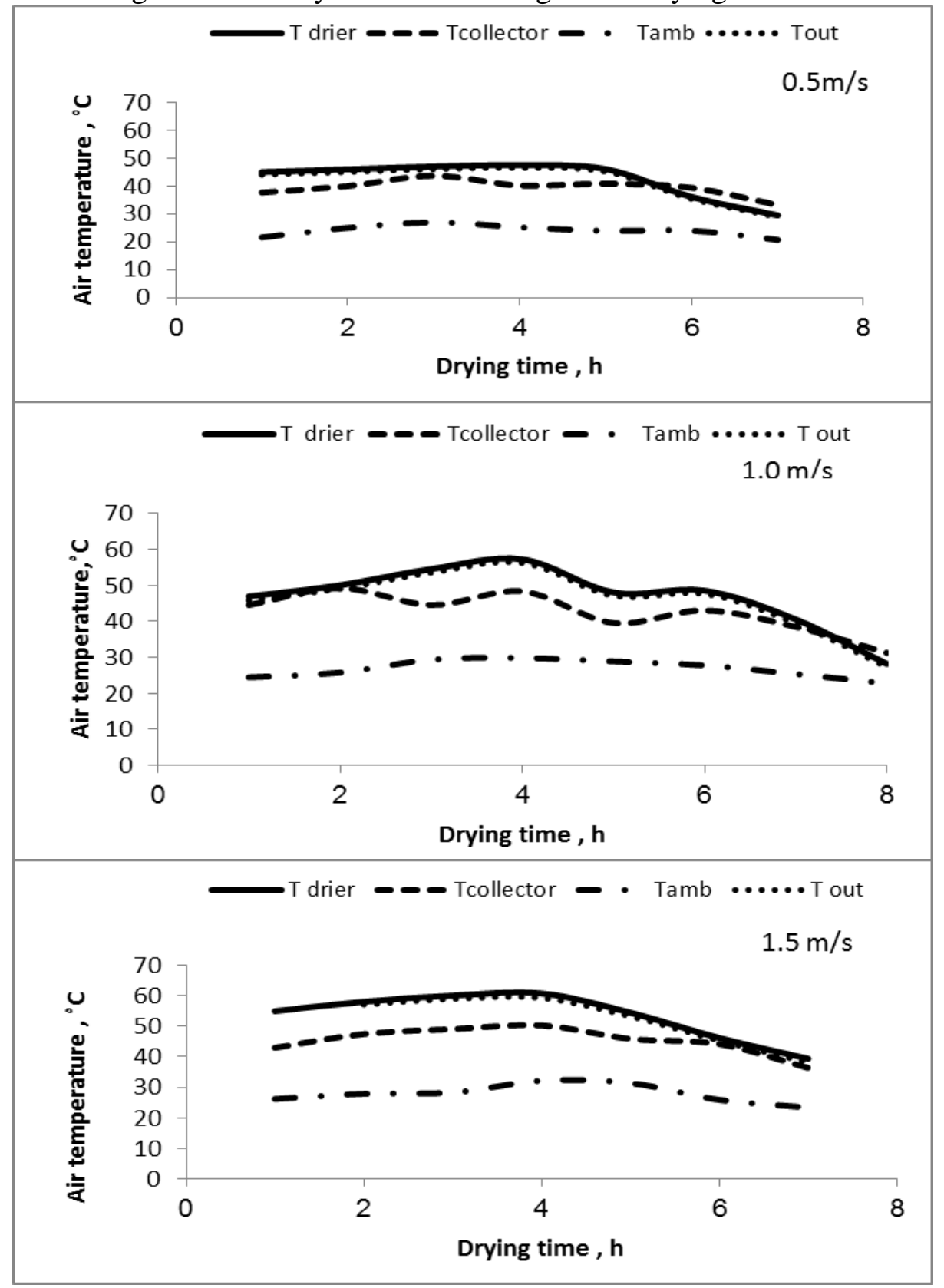

Figure 5. Air temperature as a function of drying time during the drying experiment at different drying air velocities 


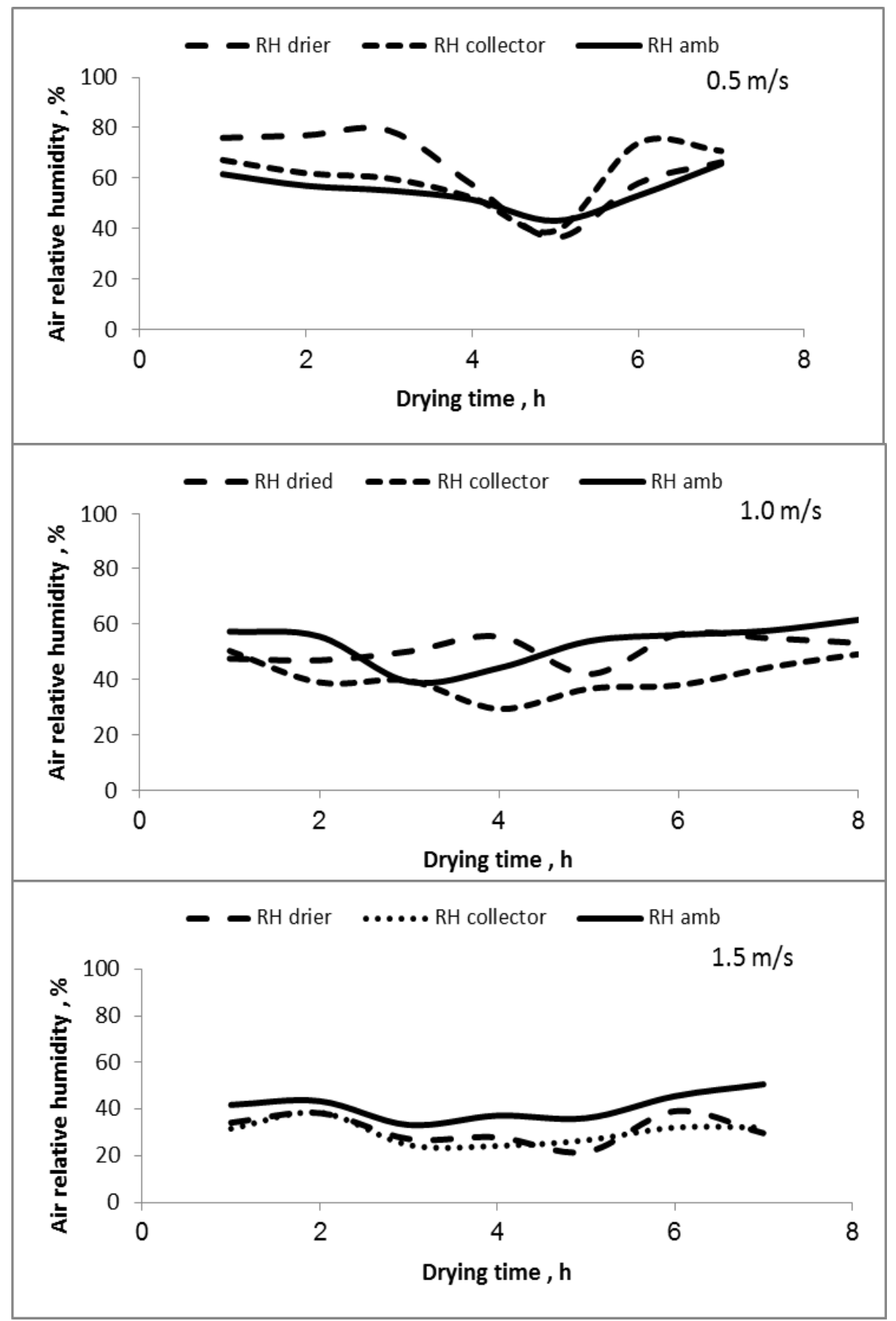

Figure 6. Air relative humidity as a function of drying time during the drying experiment at different drying air velocities 
the drying air doesn't reach stability at the moment of entering drying chamber (ranged from 0.008123 to $0.008324 \mathrm{~kg}$ water $/ \mathrm{m}^{3}$ dry air) according to drying chamber air temperature. The specific enthalpy of the semi-cylindrical solar drier was higher than that of the two others (ambient and collector). Also the specific enthalpy inside the solar collector has higher values than that of the ambient specific enthalpy at all drying air velocities. Figure 8 shows the maximum values of specific enthalpy of $192.53,229.47$ and $159.41 \mathrm{~kJ} / \mathrm{kg}$ inside the solar drier at 0.5 , 1.0 and $1.5 \mathrm{~m} / \mathrm{s}$, respectively. While, the maximum values of specific enthalpy inside the solar collector were of 133.93, 126.49 and $100.41 \mathrm{~kJ} / \mathrm{kg}$ at $0.5,1.0$ and $1.5 \mathrm{~m} / \mathrm{s}$, respectively. Ambient air specific enthalpy had the lowest values of 58.57, 63.14 and $61.06 \mathrm{~kJ} / \mathrm{kg}$ at $0.5,1.0$ and $1.5 \mathrm{~m} / \mathrm{s}$ respectively. In general, specific enthalpy of drying air increases by increasing drying air velocity. Figure 9 shows the heat energy gained by the solar collector at drying air velocity of $0.5 \mathrm{~m} / \mathrm{s}$ ranged from 70.33 to $56.2 \mathrm{~W}$ during the daytime period from (11:00AM, $2 \mathrm{dh})$ to (4:00PM, 7dh). The maximum heat energy gained of $78.67 \mathrm{~W}$ was obtained at (12:00PM, 3dh). The heat energy gained by the solar collector ranged from 216.95 to $119.33 \mathrm{~W}$ during the daytime from (11:00AM, 2dh) to $(4: 00 \mathrm{PM}, 7 \mathrm{dh})$ at drying air velocity of $1.0 \mathrm{~m} / \mathrm{s}$. The maximum heat energy gained of $216.95 \mathrm{~W}$ was obtained at (11:00PM, 2dh). The heat energy gained by the solar collector ranged from 287.51 to $174.57 \mathrm{~W}$ at daytime from (11:00AM, 2dh) to (4:00PM, 7dh) at drying air velocity of $1.5 \mathrm{~m} / \mathrm{s}$. The maximum heat energy gained of $287.51 \mathrm{~W}$ was obtained at (11:00PM, 2dh). Figure 10 shows that at (1:00PM, 4dh) at drying air velocity of $0.5 \mathrm{~m} / \mathrm{s}$ and at $(10: 00 \mathrm{AM}, 1 \mathrm{dh})$ to $(12: 00 \mathrm{PM}, 3 \mathrm{dh})$ at drying air velocity of $1.0 \mathrm{~m} / \mathrm{s}$, the exergy summation is $-0.3566 \mathrm{~kJ} / \mathrm{kg}$ drying air and ranged from -0.5801 to $-0.055 \mathrm{~kJ} / \mathrm{kg}$ drying air, respectively. When the exergy summation has a minus sign, the drying process uses this amount from the exergy carried by drying air from the solar collector and if the exergy summation is positive, the drying process doesn't need any exergy stored in the drying air but vice versa it adds exergy to the drying air and only uses some amount of the exergy gained by drying chamber, and hence the solar collector is not needed at these moments. Also it can be concluded that when ambient air temperature increases the exergy losses increases. 

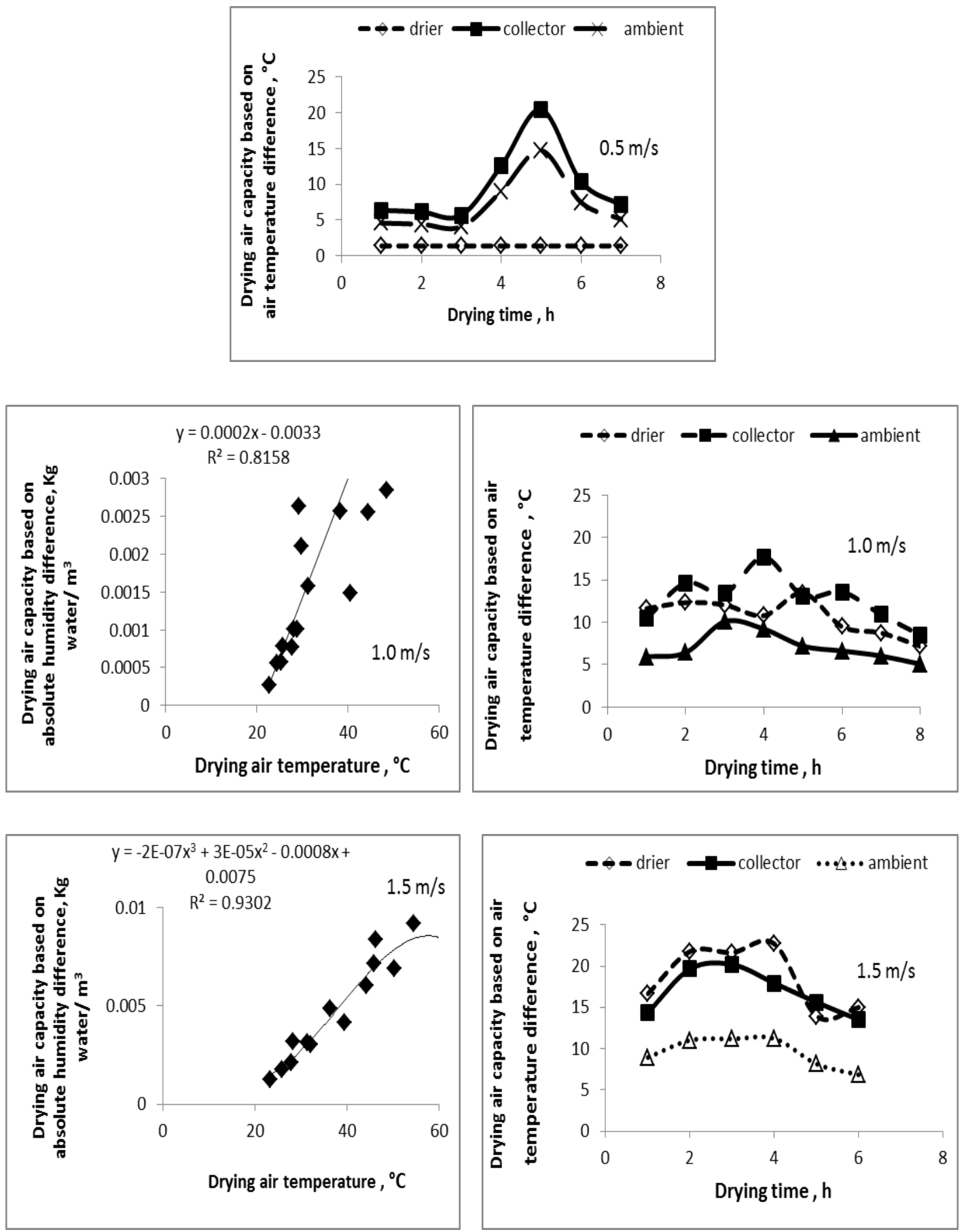

Figure 7. The effect of drying air temperature on drying air capacity based on air absolute humidity and air temperature differences at different drying air velocities 


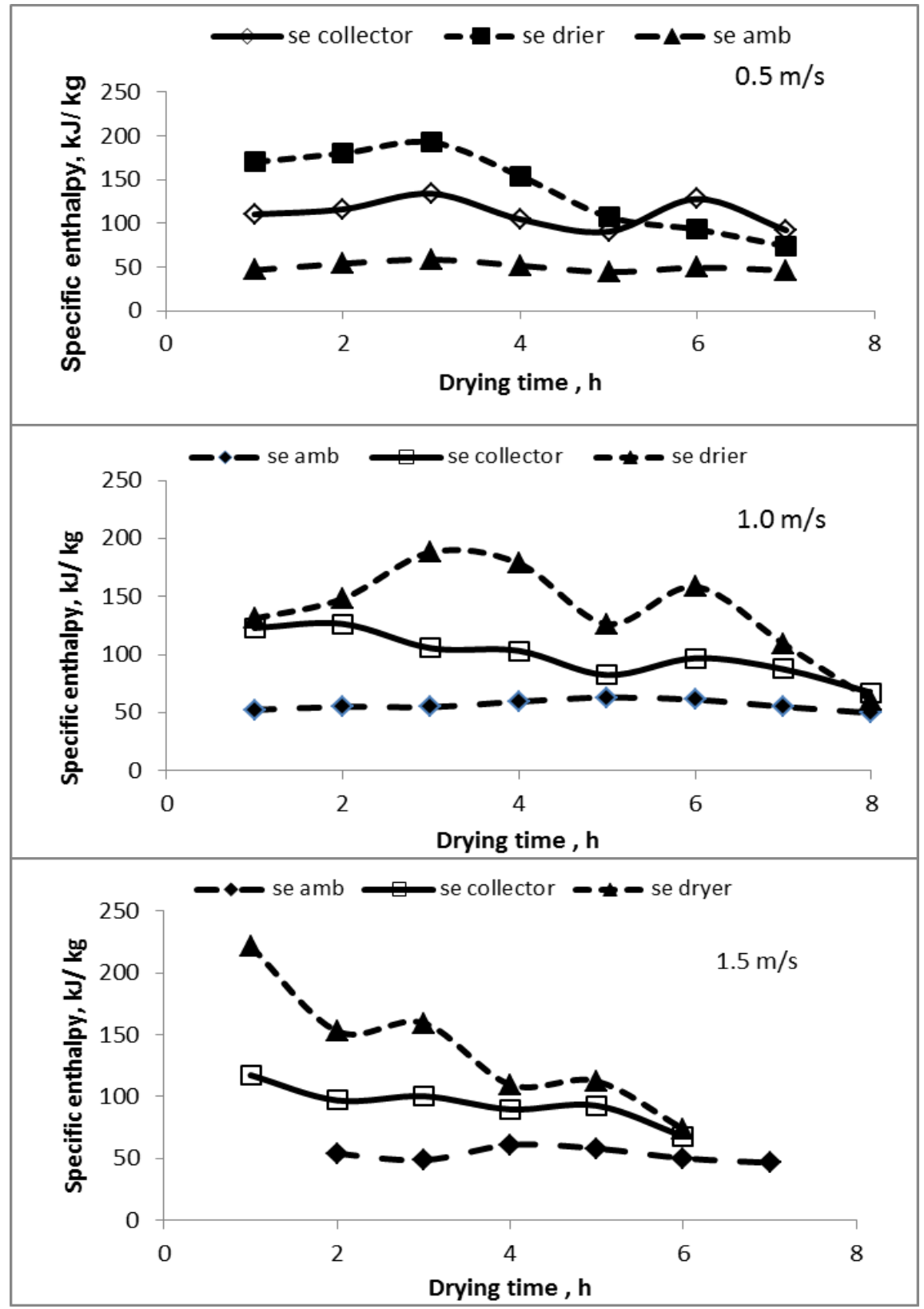

Figure 8. Specific enthalpy of the drying air as affected by drying time at different drying air velocities 


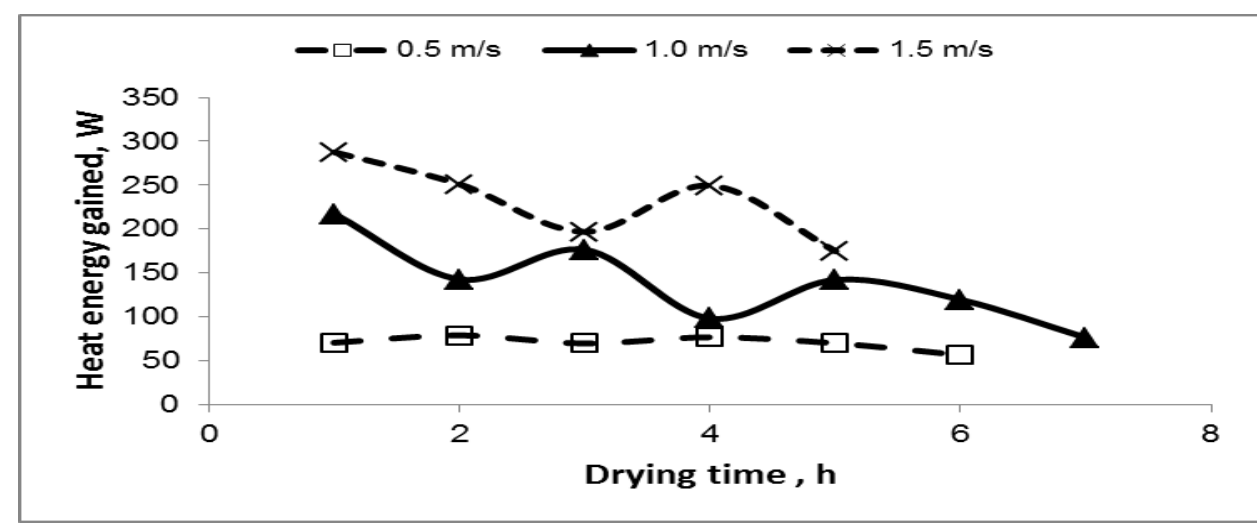

Figure 9. The heat energy gained by the solar collector as a function of drying time at different drying air velocities

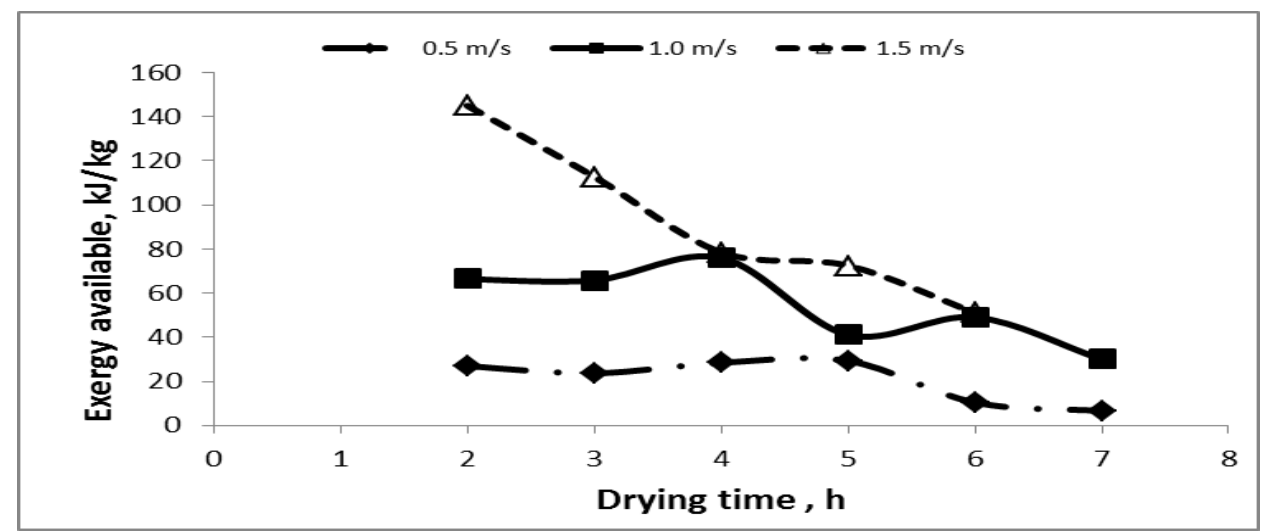

Figure 10. The exergy available as a function of drying time at different drying air velocities

It is observed from Figure 11 that, there are three different drying rate curves; the drying rate curve profile at drying air velocity of $0.5 \mathrm{~m} / \mathrm{s}$ is higher than that of 1.0 and $1.5 \mathrm{~m} / \mathrm{s}$. In case of peas residues chopping length of $6 \mathrm{~cm}$ and bed depth of $5 \mathrm{~cm}$ at daytime (12:00PM, 3dh), moisture content was high at the beginning of the drying process and lead to condensation at the drier atmosphere from residues resulting in reducing drying rate to a negative value and at daytime of (2:00PM, d5h), it increases until it reached $48.44 \mathrm{~kg}$ water $/(\mathrm{kg}$ dry matter. min $)$ and then began to decrease with the time until arrived at $30.21 \mathrm{~kg}$ water $/(\mathrm{kg}$ dry matter. min) at (5:00 PM, 8dh). The same behavior was found at drying air velocities of 1.0 and $1.5 \mathrm{~m} / \mathrm{s}$. 

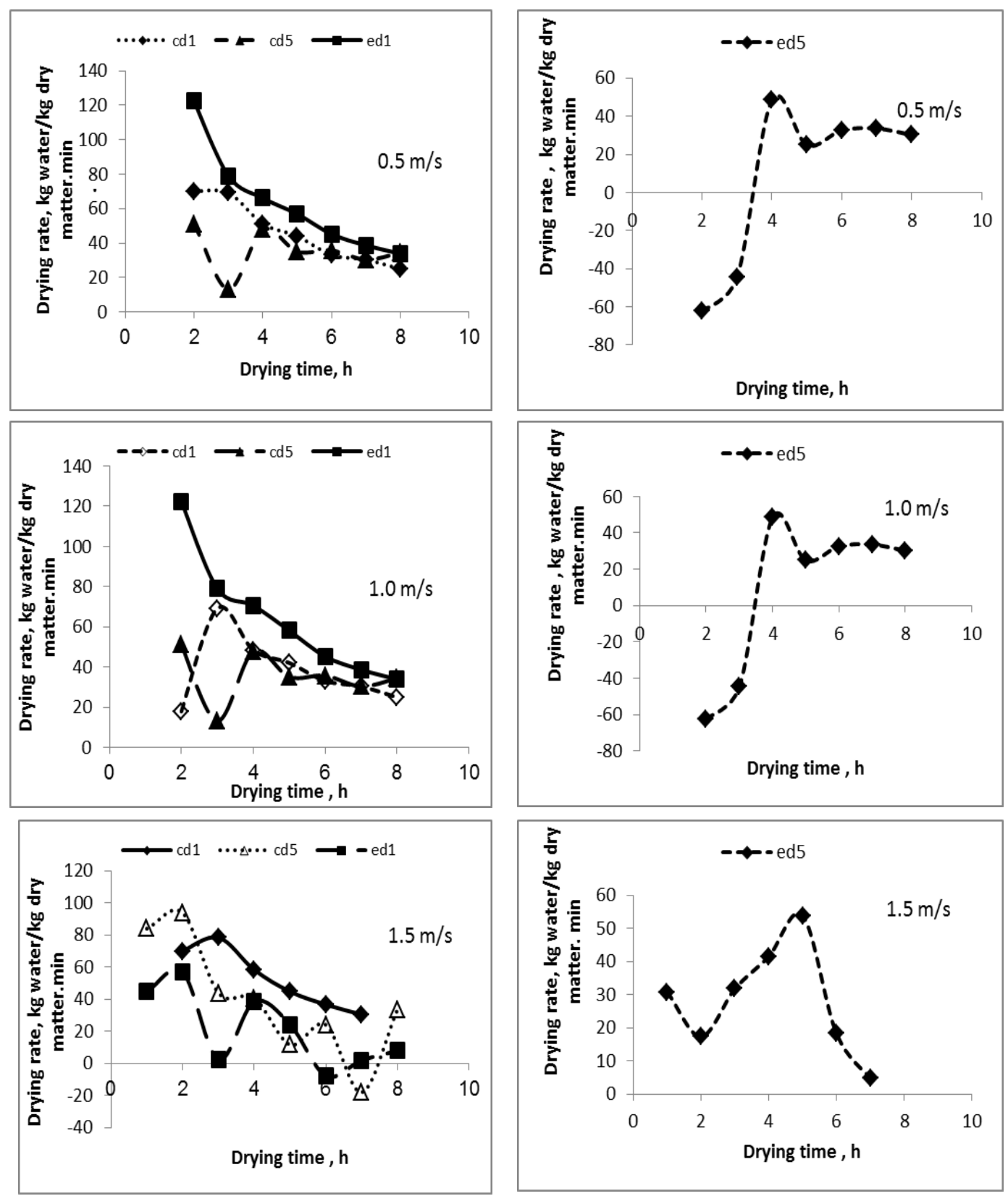

Figure 11. Evolution of drying rate as affected by drying time at different drying air velocities, different chopping lengths and different drying bed depths

At drying air velocity of $0.5 \mathrm{~m} / \mathrm{s}$, the drying process started at (11:00AM, $2 \mathrm{dh}$ ) and extended to increase to (5:00PM, 8dh). Figure 12 shows the 
reduction in drying efficiencies is due to the solar energy starts to be lower and the amount of heat energy stored in the drier and product is still used in evaporation. Also at drying air velocity of $1.0 \mathrm{~m} / \mathrm{s}$, the drying efficiencies are starting lower with values of 2.55 to $11.36 \%$, and decrease to -29.8 at $(4: 00 \mathrm{PM}, 7 \mathrm{dh})$ due to condensation and gaining moisture from the ambient air. The acquisition of solar energy from the ambient air as well as the temperature inside the greenhouse drier and waste heat itself led to increase the drying efficiency. The same behavior was found at drying air velocity of $1.5 \mathrm{~m} / \mathrm{s}$. It was noticed that the drying air velocity of $1.5 \mathrm{~m} / \mathrm{s}$ achieved the highest drying efficiency of $68.28 \%$ at (12:00PM, 3dh). The productivity of the solar drier was of $1.186 \mathrm{~kg}$ dried peas residues $/ \mathrm{m}^{2}$ of the experimented drier box per day. The drying rate was selected as the most effective indicator in the current study and can be estimated at the optimum drying air velocity of $1.5 \mathrm{~m} / \mathrm{s}$ as follows:

$$
\begin{aligned}
& \mathrm{DR}=388.0921-6.3796 \mathrm{~T}+0.248 \mathrm{SR}+2.415 \mathrm{dep}-11.34 \mathrm{CL}-0.213 \mathrm{Se}- \\
& 0.171 \mathrm{MC}+0.285 \mathrm{AC}-1.395 \mathrm{Eng}+2.087 \mathrm{Exg} \quad \mathbf{R}^{2}=\mathbf{0 . 8 0 9 4} \text { Eqn } 9
\end{aligned}
$$

Where;

DR: Drying rate, $\mathrm{Kg}$ water/(kg dry matter. $\mathrm{min})$

MC: Moisture content, $\mathrm{kg}$ water/ kg dry matter \%db.

$\mathrm{CL}$ : Chopping length, $\mathrm{cm}$

$\mathrm{T}$ : Temperature of drying chamber, ${ }^{\circ} \mathrm{C}$

$\mathrm{SR}$ : Solar radiation, $\mathrm{W} / \mathrm{m}^{2}$

AC: Drying air capacity based on temperature difference, ${ }^{\circ} \mathrm{C}$

Se: Specific enthalpy, KJ/kg

Eng: Energy, W

Exg: Exergy, kJ/kg

Dep: Drying bed debth, cm

This developed equation is valid only within the range of application. 
PROCESS ENGINEERING
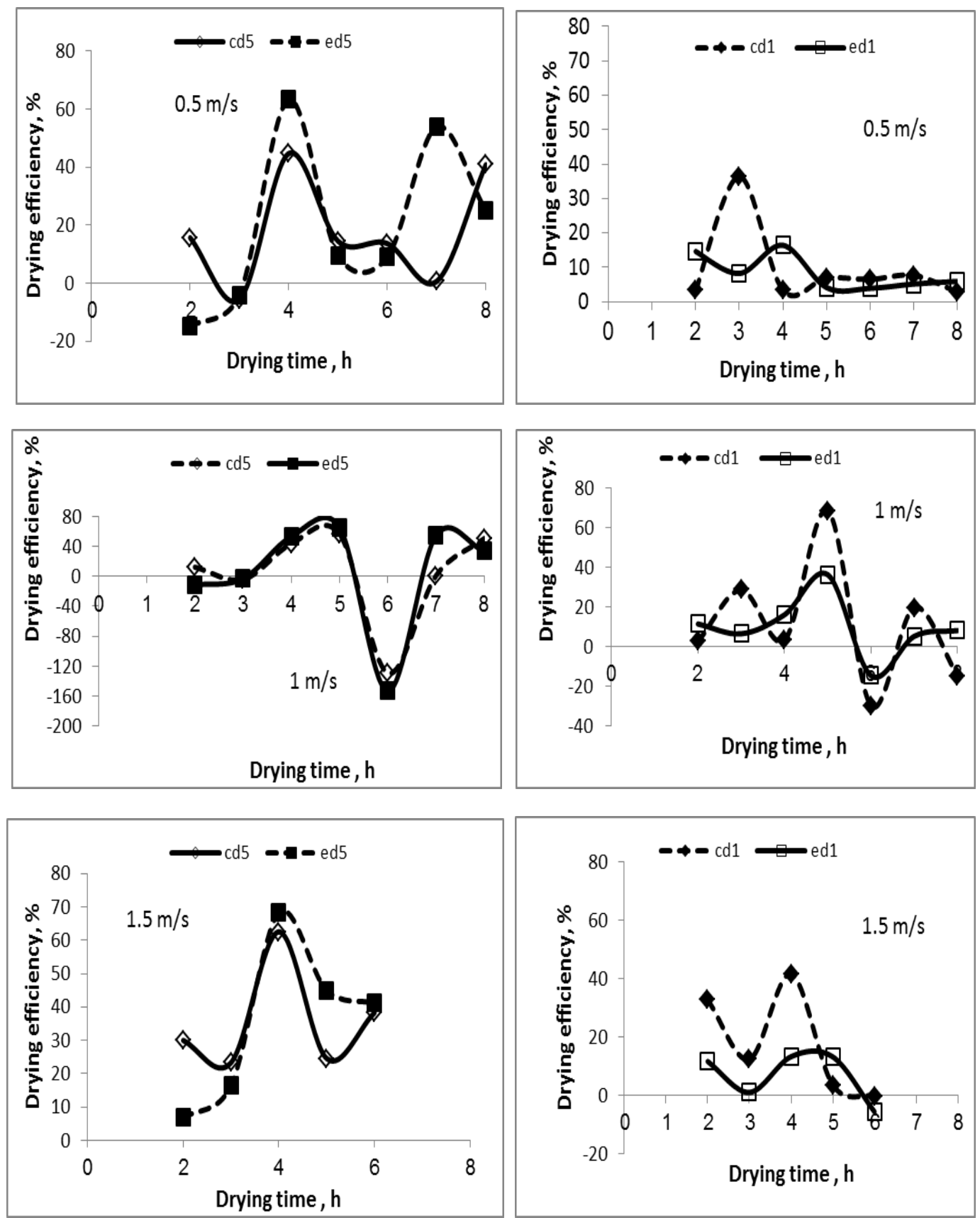

Figure 12. Evolution of drying efficiency with the drying time at different drying air velocities, different chopping lengths and different drying bed depths 
Chemical composition of peas residues is presented in Table 1. It is revealed that crude protein, ash, NFE and ether extract increased as a dry matter.

Table 1. Chemical composition of fresh and dried peas residues

\begin{tabular}{|l|c|c|c|c|l|}
\hline Item & $\begin{array}{c}\text { Crude } \\
\text { fiber, cf }\end{array}$ & $\begin{array}{c}\text { Crude } \\
\text { protein, cp }\end{array}$ & $\begin{array}{c}\text { Ether } \\
\text { extract, EE }\end{array}$ & Ash & NFE \\
\hline Fresh peas residues & 47.6 & 1.88 & 0.24 & 2.5 & 8.34 \\
\hline Dried peas residues & 23.8 & 9.4 & 1.2 & 12.5 & 41.7 \\
\hline
\end{tabular}

\section{CONCLUSIONS}

The drying air velocity of $1.5 \mathrm{~m} / \mathrm{s}$ was the most effective in increasing drying air capacity because of (Thermo stratification) and achieves the highest drying rate compared to 0.5 and $1.0 \mathrm{~m} / \mathrm{s}$. The drying air velocity of $1.5 \mathrm{~m} / \mathrm{s}$ achieved the highest exergy of $144.94 \mathrm{~kJ} / \mathrm{kg}$ drying air and has the highest heat energy gained of $287 \mathrm{~kJ}$. The moisture content decreases at drying air velocity of $1.5 \mathrm{~m} / \mathrm{s}$, ensuring the highest drying rate of $0.0938 \mathrm{~kg}$ water/(kg dry matter. min) for peas residues drying bed depth of $5 \mathrm{~cm}$ and peas residues chopping length of $3 \mathrm{~cm}$. The maximum values of specific enthalpy at drying air velocities of $0.5,1.0$ and $1.5 \mathrm{~m} / \mathrm{s}$ were of 192.53 , 229.47 and $159.41 \mathrm{~kJ} / \mathrm{kg}$ inside the drying chamber respectively. In contrast ambient air specific enthalpy had the lowest values of 58.57, 63.14 and $61.06 \mathrm{~kJ} / \mathrm{kg}$ at $0.5,1.0,1.5 \mathrm{~m} / \mathrm{s}$, respectively. The drying air velocity of $1.5 \mathrm{~m} / \mathrm{s}$ achieved the highest drying efficiency of $68.28 \%$ at (12:00PM, 3dh). Peas residues chopping length of $6 \mathrm{~cm}$ and drying bed depth of $5 \mathrm{~cm}$ were the most suitable residues distribution on the drying trays. The productivity of the solar drier was of $1.186 \mathrm{~kg}$ dried peas residues $/ \mathrm{m}^{2}$ of the experimented drier box per day. The highest drying rate of $0.0938 \mathrm{~kg}$ water/ ( $\mathrm{kg}$ dry matter. min) has been achieved at the optimum operating conditions as drying air velocity of $1.5 \mathrm{~m} / \mathrm{s}$ and chopping length of $3 \mathrm{~cm}$ and drying bed depth of $5 \mathrm{~cm}$ from peas residues.

\section{REFERENCES}

Abdallah, S. E. 1999. Utilization of solar energy in agricultural purposes: Applications of solar energy collected by a plastic greenhouse for 
drying and aerating of wheat crop. Unpublished M. Sc. Thesis, Department of Agricultural Mechanization, Faculty of Agriculture, Kafr Elsheikh, Tanta University, Egypt.

Abdallah, S. E. 2010. Thermal efficiency enhancement of a solar drier for hay making from sugar beet tops. AMA-Agricultural Mechanization in Asia Africa and Latin America, 41(4): 87-98.

Abdelatif, S. M. 1989. A comparative study of the performance of solar panels with different diameters of copper pipes. Misr J. Ag. Eng., 6 (1): 69-77.

Abou- Zaher, S.E., 1998. Environmental control systems of agricultural structure "A simulation study on broiler housing systems". Unpub. Ph. D. Thesis. Department of Agricultural Mechanization, Faculty of Agriculture, Kafr El-Sheikh, Tanta University, Egypt.

Akbulut, A. and A. Durmus. 2010. Energy and exergy analyses of thin layer drying of mulberry in a forced solar drier. Energy, 35: 17541763.

Akpinar, E. K.; A. Midilli and Y. Bicer. 2005. Energy and exergy of potato drying process via cyclone type drier. Energy Conservation and Management, 46: 2530-2552.

Akpinar, E. K.; A. Midilli and Y. Bicer. 2006. The first and second law analyses of thermodynamic of pumpkin drying process. Journal of Food Engineering, 72: 320-331.

Ali, M. F. (1996). The use of treated and untreated sugar beet by-products in feeding farm animals. Ph. D. Thesis, Fac. of Agric. Kafr ElSheikh, Tanta Univ., Egypt.

ASAE. 1996. Moisture Measurement- Forage. ASAE Standard D499.3, American Society of Agricultural Engineers. St. Joseph. MI.

Banerjee, R. 2005. Capacity building for renewable energy in India. Proceedings of International Congress on Renewable Energy (ICORE 2005), January, Pune India: 77-83. 
Banout, J; P. Ehl; J. Havlik; B. Lojka; Z. Polesny and V. Verner. 2011. Design and performance evaluation of a Double-pass solar drier for drying of red chilli (Capsicum annum L). Solar Energy, 85: 506515 .

Boulemtafes-Boukadoum, A. and A. Benzaoui. 2011. Energy and exergy analysis of solar drying process of mint. Energy Procedia, 6: 583591.

Celma, A. R. and F. Cuadros. 2009. Energy and exergy analyses of solar drying process. Renewable Energy, 34: 660-666.

Dincer, I. 2002. On energetic, exergetic and environmental aspects of drying systems. International Journal Research, 26: 717-727.

Doymaz, I. 2005. Drying characteristics and kinetics of okra. Journal of Food Engineering, 69: 275-279b.

Ekechukwu, O. V. and B. Norton. 1998. Review of solar energy drying systems II: an overview of solar drying technology, Energy Conservation and Management, 40: 615 -655.

Eldreeny, A.G.F. 2015. Process engineering of agricultural and industrial wastes: Engineering aspects for processing agricultural and industrial wastes. Unpublished M.Sc. Thesis, Department of Agricultural Engineering, Faculty of Agriculture, Kafrelsheikh University.

El-Kewey, A. A. 2003. Utilization of solar heated and ambient air for drying rough rice for several harvest periods. Unpublished $\mathrm{Ph}$. D. Thesis, Department of Agricultural Mechanization, Faculty of Agriculture, Kafr Elsheikh,Tanta University, Egypt.

El-Mashad , H. M. 2003. Reuse potential of agricultural wastes in semiarid regions: Egypt as a case study. Reviews in Environmental Science \& Biotechnology, 2: 53-66. 
El-Sahrigi, A. F.; M. A. El-Refaie; S. M. Abdelatif and O. K. Mohamed. 1993. Utilization of solar energy in agricultural crop drying. Misr J. Ag. Eng., 10 (3): 402-417.

El-Sebaii, A. A.; S. Aboul-Enein; M. R. Ramadan and H. G. ElGohary. 2002. Empirical correlations for drying kinetics of some fruits and vegetables. Energy, 27(9): 845-859.

Fudholi, A.; K. Sopian; M. Y. Othman and M. H. Ruslan. 2014. Energy and exergy analyses of solar drying system of red seaweed. Energy and Buildings, 68: 121-129.

Lamnatou, Chr.; E. Papanicolaou; V. Belessiotis and N. Kyriakis. 2012. Experimental investigation and thermodynamic performance analysis of a solar drier using an evacuated-tube air collector. Applied Energy, 94: 232-243.

Leon, M. A.; S. Kumar and S. C. Bhattacharya. 2002. A comprehensive procedure for performance evaluation of solar food driers. Renewable and Sustainable Energy Reviews, 6: 367-393.

MOA. 2013. Ministry of Agriculture.

Midilli, A. and H. Kukuk. 2003. Energy and exergy analyses statistics of solar drying process of pistachio. Energy, 28: 539-556a.

Nikbakht, A. M.; A. Motevali and S. Minaei. 2013. Energy and exergy investigation of microwave assisted thin-layer drying of pomegranate arils using artificial neural networks and response surface methodology. Journal of the Saudi Society of Agricultural Sciences. 13: 81-91.

Pangavhane, D. R.; R. L. Sawhney and P. N. Sarasva. 2002. Design and development and performance of testing of a new natural convection solar drier. Energy, 27: 579-590.

Prommas, R.; P. Rattanadecho and D. Cholaseuk. 2010. Energy and exergy analyses in drying process of porous media using hot air. International Communications in Heat and Mass Transfer, 37: 372378. 


\section{الملخص العربى}

هندسة إنتاج العلف بواسطة التجفيف الشمسى لمخلفات محاصيل الخضر الثربير

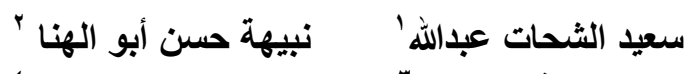

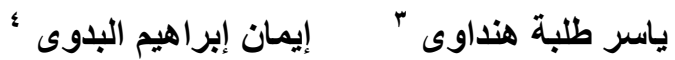

انخفضت مصادر الغذاء للإنتاج الحيوانى مما أثر على الاستهلاك الأدمى ـ ازدادت المشكلة فى هذة الأيام نتيجة اتجاة الحكومة الى زيادة انتاجية محاصيل الحبوب الرئيسية مثل القمح فى في

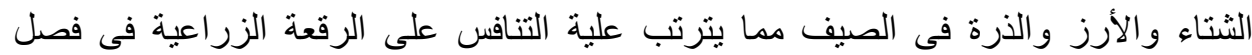
الصيف والشتاء مما أدى الى زيادة اسعار الأعلاف التقليدية خاصة فى الثتاء مثل البرسيم. تعتبر مخلفات المحاصيل والخضر من اهم المخلفات الزراعية وذلك لان قيمتها الغذائية عالية ومن ضمن هذة المخلفات مخلفات البسلة وتعد مصر سادس دول العالم فى انتاج البسلة حيث تنتج

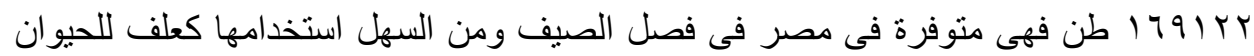

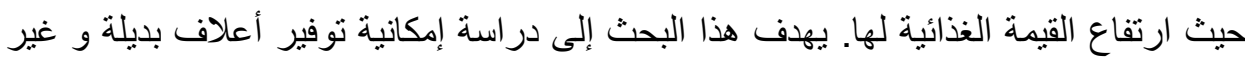
تقليدية فى فصل الثتاء جنباً الى جنب مع فصل الصيف عن طريق دراسة تجفيف مخلفات

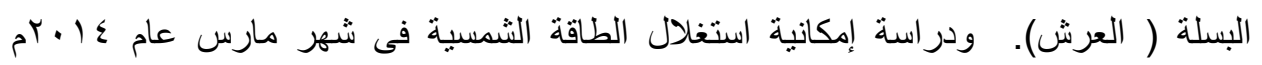
لتجفيف مخلفات البسلة عن طريق إستخدام صوبة نصف اسطوانية تحت سرعات هو اء تجفيف مختلفة وظروف تحميل مختلفة. تم در اسة المتغير ات و العناصر الأتية:

تأثثر سرعات هو اء التجفيف المختلفة على تطور عملية التجفيف من خلال معدل التجفيف

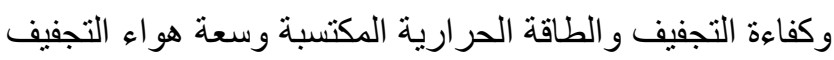

در اسة تأثير أطو ال القطع على كفاءة عملية التجفيف در اسة خواص هو اء التجفيف

در اسة سلوك عملية التجفيف مع تغيير عمق طبقة التجفيف عن طريق:

$$
\text { أـ المحتوى الرطوبي على أساس رطب و على أساس جاف }
$$

ب- معدل التجفيف

اـ أستاذ هندسة التصنيع الزراعى المساعد، قسم الهندسة الزراعية، كلية الزراعة، جامعة كفر الثيخ ،كفر الثيخ

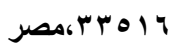

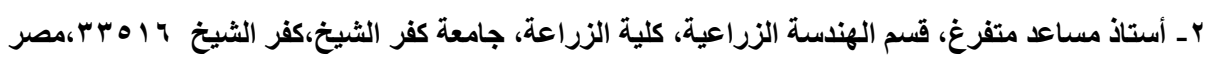

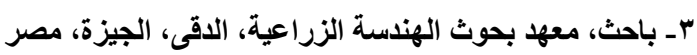

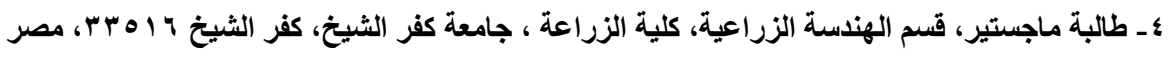


تم قياس سعة هواء التجفيف (الفرق بين الرطوبة المطلقة أو درجة الحرارة الإبتدائية

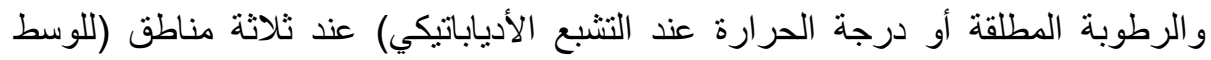

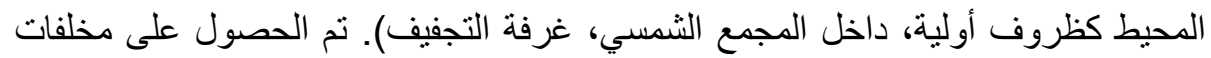

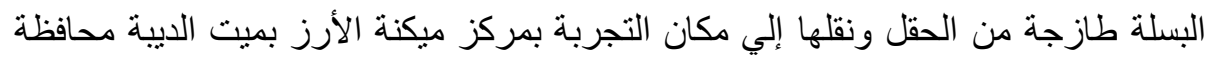

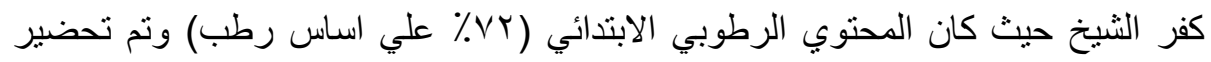

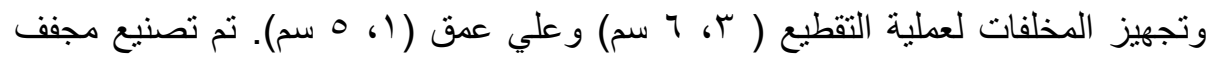
شمسى من نوع الصوبة نصف الإسطوانية في مركز ميكنة الأرز بميت الديبة، محافظة ولمية

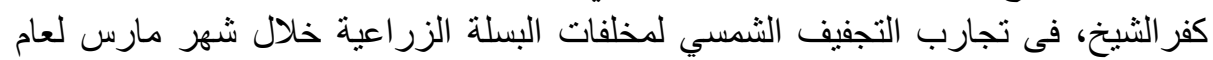

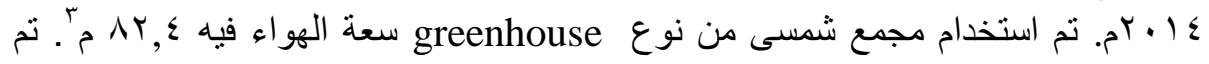
توصيل المجفف الثمسى بالمجمع الثمسى ،وتم استخدام طولين لتقطيع مخلفات البسلة

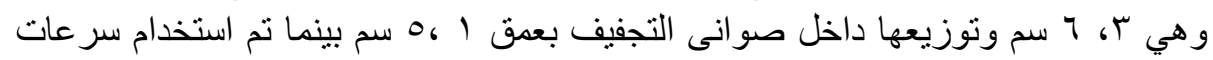

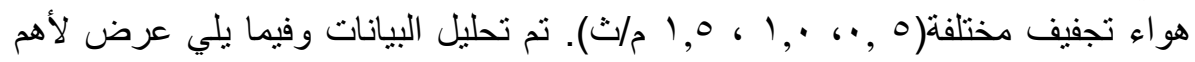

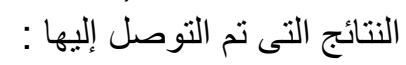

ا - سرعة هو اء التجفيف 0, 1, م/ث هى أكثر السرعات تأثيراً على زيادة سعة هواء

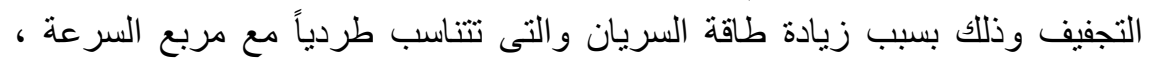
فيزداد سعة هو اء التجفيف بزيادة سر عة هو اء التجفيف.

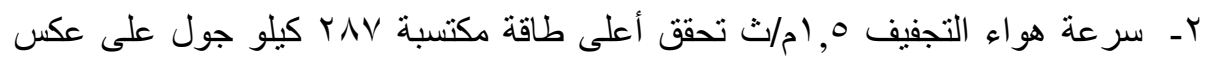
السر عات ( 0, ، ، •, ام/ت) و التى تحقق طاقة مكتسبة أقل.

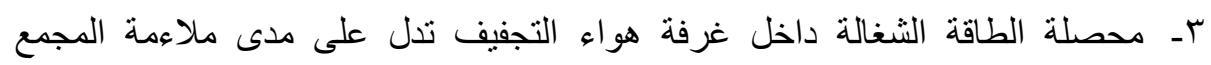

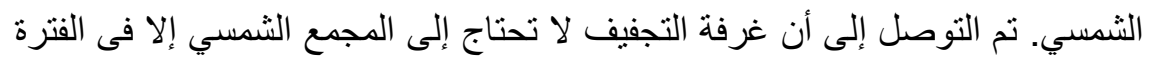

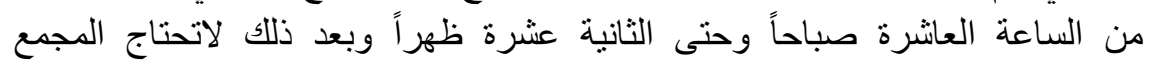

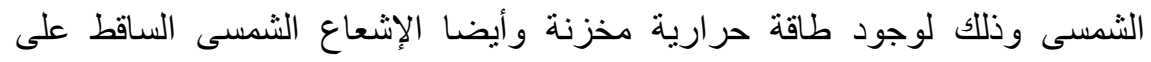
المجفف.

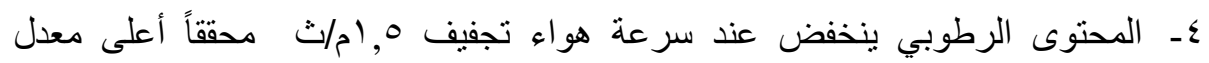
تجفيف ^به • , . ، كج ماء/دقيقة لعمق طبقة تجفيف هسم وطول قطع ساسم. هـ معدل التجفيف يتأثر بعدة عوامل مثل الإنثالبيا النوعية، سعة هواء التجفيف، كمية

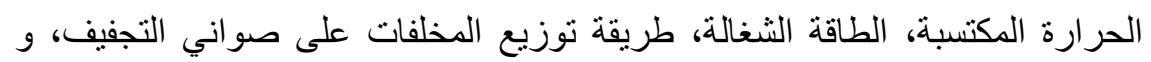
أخيراً المحتوى الرطوبى. كل هذه العوامل لها تأثير على معدل التجفيف وتم تقدير

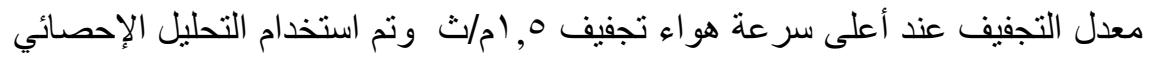
المتعدد الإنحدار وتم الحصول على المعادلة الأتية: $\mathrm{DR}=388.0921-6.3796 \mathrm{~T}+0.248 \mathrm{SR}+2.415 \mathrm{dep}-11.34 \mathrm{CL}-0.213 \mathrm{Se}-$ $0.171 \mathrm{MC}+0.285 \mathrm{AC}-1.395 \mathrm{Eng}+2.087 \mathrm{Exg} \quad \mathrm{R}^{2}=0.8094$ 


$$
\begin{aligned}
& \text { حيث مع معل التجفيف، كج ماء/ كج مادة جافة. دقيقة } \\
& \text { سعة هو اء التجفيف، درجة مئوى AC } \\
& \text { Se } \\
& \text { المحتوى الرطوبى لعرش البسلة، \% أساس رطب } \\
& \text { SR الإشعاع الثمسى الساقط، وات/م } \\
& \text { T درجة حرارة هو اء غرفة التجفيف، درجة مئوية } \\
& \text { CL } \\
& \text { Dep } \\
& \text { كُّية الطاقة المكتسبة، وات Eng } \\
& \text { Exg الطاقة الشغالة المتاحة ، كيلوجول/كج }
\end{aligned}
$$

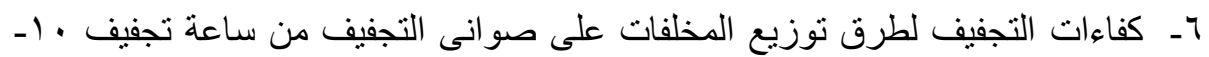

1 ساعة، أعلى كفاءة تجفيف كانت لطول قطع المخلفات آسم مع عمق طبقة تجفيف

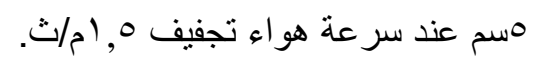

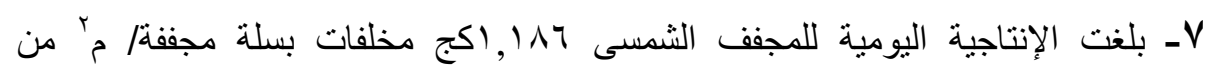

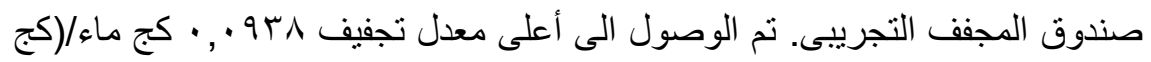

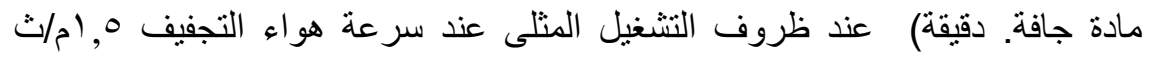

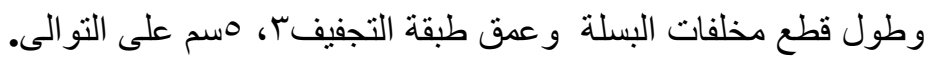

